ELORE (ISSN 1456-3010), vol. 16 - 2/2009.

Julkaisija: Suomen Kansantietouden Tutkijain Seura ry.

[http://www.elore.fi/arkisto/2_09/katsart_apo_2_09.pdf]

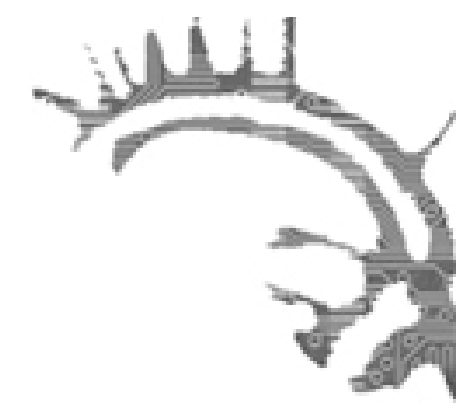

KATSAUSARTIKKELI

\title{
UUSIN LÖNNROT-MYYTTI JA KANSANRUNOUDEN EDITIOHISTORIA
}

\section{$\underline{\text { Satu Apo }}$}

Editiohistoria on yksi uusimmista tulokkaista folkloristien käyttämien tutkimusotteiden valikkoon. Löysin sen perehtyessäni kansanrunouden kirjallistamisen pyhään alkuun, 1700-luvun klassikkojulkaisuihin (J. Macpherson, T. Percy, J. G. Herder). (Ks. Apo 2006; Stafford 1988; Groom 1999.) Folkloreen pohjaavien julkaisujen tarkasteleminen editiohistorian näkökulmasta edellyttää kohteen lähestymistä sekä kirjallisuustieteen että kansanrunoudentutkimuksen kautta. Kulttuurihistoria kytkeytyy mukaan lähes väistämättä, usein myös kielihistoria. Lönnrotiin ja hänen aikalaisiinsa liittyvät editiohistorialliset kysymykset tulivat ajankohtaisiksi kirjoittaessani osuuttani Kalevalan kulttuuribistoriaan (2008). Kävin läpi muiden muassa Carl Axel Gottlundin ja Daniel E. D. Europaeuksen runojulkaisut ja pohdin, miltä ne näyttävät suhteessa niihin kansallisiin ja kansainvälisiin odotushorisontteihin, jotka koskivat kansanrunoutta ja kirjallisuutta 1830-1840-luvulla.

Irma Sulkunen julkaisi vuonna 2004 Suomalaisen Kirjallisuuden Seuran historian ensimmäisen osan; tämän tutkimuksen aikajänne kattaa vuodet 1831-1892. Teoksen kolmessa ensimmäisessä pääluvussa käsitellään 1830- ja 1840-lukua. Tällöin tapahtumien kulku lepää suurelta osin sekä historiallisesti että Sulkusen esittämänä Elias Lönnrotin ja hänen päteostensa, Kalevalan ensimmäisen (1835) ja toisen edition (1849) varassa. Lönnrotin kolmannen pääteoksen, niin ikään 1840-luvulla ilmestyneen Kantelettaren, Sulkunen kuittaa vain muutamalla maininnalla.

Sulkusen näkemyksen mukaan eepos ja sen suurmieheksi nostettu tekijä jättivät varjoonsa huomionarvoisia miehiä, jotka toimivat samalla kulttuurisella kentällä ja samoin tavoittein ja keinoin, pyrkien edistämään suomen kielen emansipaatiota ja suomenkielisen kirjallisuuden kehkeytymistä tallentamalla ja julkaisemalla kansanrunoutta. Lönnrotin vastapelureiksi Sulkunen on valinnut Gottlundin (1796-1875) ja 


\section{Satu Apo}

Europaeuksen (1820-1884). Sulkusen rakentamassa draamassa Gottlund ja Europaeus esitetään valtakamppailun uhreina. Heidät ajoi sivuraiteelle kaksi tekijää. Näistä ensimmäinen oli Lönnrotin luonteen pimeä puoli, jota ei tähänastisessa tutkimuksessa ole nostettu riittävästi esiin. Toinen oli suomalaisuusliikkeen synnyttämä Kalevala- ja Lönnrot -kultti. Tärkein kulttiyhteisö oli Suomalaisen Kirjallisuuden Seura.

Tarkastelen katsausartikkelissani Irma Sulkusen esittämiä tulkintoja Lönnrotin, Gottlundin ja Europaeuksen muodostamasta kolmiosta. Ennen kuin ryhdyn dekonstruoimaan Sulkusen rakennelmaa, esittelen omat premissini. Muistutan ensin tieteenalaamme koskien, ettei suomalainen folkloristiikka ole viimeisen sadan vuoden aikana seissyt, noussut eikä kaatunut Kalevalaan tai sen tekijään nojaten. Pidän kiistattomana, että Lönnrot sai aikalaistensa silmissä suurmiehen aseman ja Kalevala miellettiin suomalaisuuden peruskiveksi viimeistään 1840-luvulta lähtien. Vaikka Lönnrot oli selvin sanoin ilmoittanut, että ne kertovat kansanrunot, joita yhdistelemällä hän oli rakentanut Kalevalan kokonaisjuonen, eivät olleet osasia ikivanhasta, sittemmin hajonneesta eepoksesta, hänen sanomansa ei mennyt perille. Kalevalan hahmottaminen muinaisen eli esihistoriallisen eepoksen rekonstruktioksi tarjosi liian houkuttelevan aseen suomenkielisen kulttuurin asiaa ajaville fennomaaneille. Kalevala sai entistä enemmän painoa, kun se Mathias Alexander Castrénin laatimana ruotsinnoksena (1841) saattoi pohjoisen periferian pienen ja alkukantaisena pidetyn kansan eurooppalaisten tutkijoiden arvostavan huomion kohteeksi.

En voi hyväksyä Sulkusen esittämiä teesejä; pidän niitä liian heikosti perusteltuina. Se, että Gottlund ja Europaeus jäivät Lönnrotin varjoon sekä aikalaisten että seuraavien sukupolvien silmissä, johtuu yksinkertaisesti heidän julkaisujensa laadusta, osittain myös määrästä. Persoonallisuudeltaan Gottlund ja Europaeus olivat heidän henkilöhistoriaansa valottavan lähdeaineiston mukaan niin hankalia, että he olisivat joutuneet vakaviin vaikeuksiin missä tiedeyhteisössä tahansa. (1) M. A. Castrén ei todennäköisesti jännt yksin kirjoittaessaan Europaeuksesta: "En idiot, en gelike till Gottlund." (2)

Kolmikon runojulkaisuja koskevat väitteeni voidaan todentaa empiirisesti, kokoamalla pöydälle kirjoittajien pääteokset, kahdeksan kirjaa. Lönnrotia edustavat kaksi monisatasivuista Kalevalaa sekä Kanteletar, Gottlundia kokoelmat Pieniä Runoja Suomen poijille Ratoxi (1819-1821), Väinämö̈set (1828), Otavaan (1831-1832) sisältyvät kansanrunot sekä kalevalamittainen, alle sadan sivun laajuinen eepos Runola (1840). Europaeus tuotti tänä aikana vain yhden kansanrunojulkaisun eli Pienen Runon-sepän (1847). (3) Näiden kirjojen selailu ja niiden esipuheiden lueskelu riittävät tuottamaan lyhyessä ajassa ymmärryksen, mihin Lönnrotin, Gottlundin ja Europaeuksen väliset arvostuserot ovat perustuneet ja perustuvat tälläkin hetkellä.

Kalevala-kulttia ja Lönnrotin pimeää puolta ei tarvittu laskemaan Gottlundin ja Europaeuksen runojulkaisuja kakkoskategoriaan myöskään siksi, että niiden ohi ajoi laadussa ja laajuudessa myös Zacharias Topeliuksen vanhemman viisiosainen kokoelma Suomen Kansan Vanboja Runoja ynnä myös nykyisempiä lauluja (1822-1831). (4) 


\section{Kuka LönNRot oli SEuraA Perustettaessa?}

Kirjallisuuden Seuran syntyä käsittelevässä luvussa Seuran perustaminen (sivut 17-40) Sulkunen esittää uuden näkemyksen Lönnrotin asemasta ja merkityksestä suomalaisuuden edistäjien joukossa 1830-luvun alkuvuosina. Lönnrotin pää ei kohonnut muita korkeammalle. Sulkunen määrittelee hänen asemansa Seuran perustamisvuonna seuraavasti:

Siitä henkilöjoukosta, joka Kirjallisuuden Seuran ympärillä tuolloin askaroi, ei kukaan ollut vielä noussut selvästi ylitse muiden - - . Etenkään Lönnrotia ei vielä leimannut se arvostus, jonka jälkipolvet ovat häneen painaneet. (Sulkunen 2004, 24.)

Tosiasiallisesti Lönnrot oli jo erityisasemassa; Seura perustettiin vaiheessa, jolloin herderiläinen käsitys kielestä ja sanataiteesta oli Suomessa vielä täydessä kukassaan: uusi laulu oli rakennettava vanhan pohjalle. Suomenkielisen kaunokirjallisuuden puuttuessa "vanha laulu" tarkoitti kansanrunoutta. Kansanperinteessä ilmeni myös kieli kaikkein puhtaimmassa ja rikkaimmassa muodossaan. Lisäksi se oli ikkuna kansan muinaisuuteen, josta oli saatavissa hyvin vähän jos ollenkaan muuta tietoa. Niinpä kansanperinne nostetaan näkyvästi esiin Seuran ensimmäisissä säännöissä. (5)

Lönnrot oli saanut ikäpolvensa suomalaisuusmiesten silmissä arvostetun aseman monista syistä: hän oli noussut suomenkielisen rahvaan syvimmistä riveistä ja lukenut itsensä filosofian maisteriksi. Lönnrotin opinnäyte Dissertatio de Väinämöine, priscorum fennorum numine (1827) kandidaatin tutkintoa varten oli käsitellyt kansanrunoutta ja -uskoa. Vuonna 1830 hän oli valmistunut myös lääketieteen kandidaatiksi; tohtorin arvo tuli kahta vuotta myöhemmin. Tämän lisäksi hän oli tehnyt merkittävän tutkimusmatkan Suomen itäisille syrjäseuduille 1828. Hän oli lähettänyt ystävilleen kertomuksia sekä seikkailuistaan että kansanelämästä. (Ks. esimerkiksi Majamaa 1990a, 9-16.) Kokoamistaan tallenteista (lähes 400 tekstiä) Lönnrot oli ehtinyt toimittaa ja julkaista jo kolme nidettä nimellä Kantele (1829-1830). Sarjan neljäs osa oli tulossa kirjakauppoihin huhtikuussa 1831, ja viides osa oli valmiiksi toimitettu painatusta varten. (Anttila 1985, 101.)

Millaisia perusteluja esitetään sille, ettei Lönnrot erottunut muista perustajajäsenistä? Ratkaisu on yksinkertainen mutta tehokas. Lukijalle ei anneta mitään tietoja Lönnrotista. Seuran muut 11 perustajajäsentä on esitelty laatikkotekstissä (Pikkanen 2004, 34-40), Lönnrotia ei. Laajaan laatikkoon on mahtunut vain Lönnrotin kuva, nimi sekä syntymä- ja kuolinvuosi. Varsinaisessa tekstissä Sulkunen luonnehtii Lönnrotia seuraavasti: "Piirilääkärin paikkaa samaan aikaan havittelevasta Lönnrotista tuli sihteeri." (Sulkunen 2004, 21.)

Lönnrotin erityisasema näkyikin Seuran toiminnassa heti. Hänelle myönnettiin kesäkuussa 1831 Seuran ensimmäinen matka-apuraha (100 ruplaa), vajaat kolme kuukautta perustamiskokouksen jälkeen. (Anttila 1985, 105.) Näyttää myös todennäköiseltä, että Lönnrotille varattiin Seuran ensimmäisen julkaisun kunniasija. Hän sai huhtikuussa 1833 tietää Seuran sihteeriltä C. N. Keckmanilta, että Seura on valmis 


\section{Satu Apo}

kustantamaan Kantele-sarjan viidennen osan. (Kaukonen 1979, 38-39; Majamaa 1990a, 36-37, 39.) Lönnrot hyväksyi tarjouksen 7. toukokuuta 1833 päivätyssä kirjeessään. Hän aikoi syksyllä tulla Helsinkiin hoitamaan sekä Kanteleen painatusta että uuteen runojulkaisuun liittyviä töitä: "Hyvä olisi, jos itse tulevana syksynä pääsisin Helsinkiin suorimaan näitä, että niitä entisiä runoja [Kanteleen IV niteen tekstejä]." (Majamaa 1990a, 36-37.) Hanke jäi kuitenkin toteutumatta osin Keckmanin Ruotsin-matkan vuoksi, osin siksi, että Lönnrot halusi kokeilla uutta toimitustapaa, kertovien kansanrunojen yhdistämistä sikermiksi. Kansanrunokirjan julkaisutarjous esitettiin siis noin vuotta aiemmin kuin Seuran ensimmäinen julkaisu näki päivänvalon. Kyseessä oli Kultala, saksalais-sveitsiläisen kansanvalistajan Heinrich Zschokken Das Goldmacherdorf -teoksen (1817) suomennos. (Ks. Pääkkönen 1994, 97-98, 111.) (6)

\section{GOTTLUNDIN SUURUUS JA LÖNNROTIN PIENUUS}

Historiansa toisessa luvussa Toiminnan vakïntuminen (sivut 41-74) Sulkunen yrittää tehdä Gottlundista Lönnrotin uhrin. Sulkunen lähtee liikkeelle havainnosta, ettei Lönnrot ole maininnut Vanhan Kalevalan esipuheessa Gottlundia muiden kansanrunoutta julkaisseiden suomalaisten rinnalla. Nämä muut ovat Christian Lencqvist, Christfried Ganander, Henrik Gabriel Porthan ja Zacharias Topelius. Sulkunen kyselee painokkaasti, miksi Gottlund on jätetty pois, vaikka Lönnrotin kirjeenvaihdosta käy ilmi, että hänellä oli ollut käytössään Gottlundin Pieniä Runoja Suomen Poïille Ratoxi ja kansanrunokokoelma Vä̈nämöiset. Lisäksi Lönnrot tunsi Otava-tietoteoksen. Otavaan sisältyy näytteitä kansanrunoudesta, mm. Ritvalan helkavirret sekä laaja valikoima sananparsia. Lönnrot toki tunsi Gottlundin tuotannon, mutta tunsiko Sulkunen sen kysyessään seuraavasti: "Eikö Gottlund saavutuksineen kansanrunouden alalla nauttinut Lönnrotin arvostusta vai pyrkikö hän mitätöimään tämän roolin kateuttaan?" Lönnrotin teko on myös voinut olla "tahattoman tarkoituksenmukainen". (Sulkunen 2004, 66.) Entäpä jos kyseessä oli järkevä rajaus, kun otetaan huomioon Kalevalan sisältö ja Gottlundin maine kansanrunojen julkaisijana?

Gottlundin Pieniä runoja -kokoelma on todella pieni. Se sisältää runotekstejä noin 55 sivun verran. Kyseessä on kirjava valikoima lyyrisiä lauluja, balladeja, metsästysloitsuja sekä karhun pyyntiin ja peijaisiin liittyviä tekstejä. Kalevalan selkäranka, sankari- ja seikkailurunot loistavat poissaolollaan, samoin myyttirunot lukuun ottamatta Pääskylintu, päivälintu -tyyppistä maailmansyntyä. Tämä lisäksi vain Kullervon sotaan lähtöä kuvaava kertauslaulu sekä yhdeksän säkeen mittainen sampofragmentti edustavat kalevalaista aihelmistoa. Pienien runojen lähdearvo oli siis Kalevalaa laativalle Lönnrotille lähes olematon.

Entä sitten Gottlundin V ä̈nämöiset? Kyseinen kirjanen sisälsi noin 130 sivun verran runoja ja niiden taustan esittelyä. Teos oli ilmestymisaikanaan todella huonoa mainosta suomalaiselle kansanrunoudelle. Gottlund oli kantanut kirjapainoon Savosta kokoilemiaan värikkäitä kyläjuoruja ja pilkkarunoja. Sisällöltään ja muodoltaan tämä runous tuskin edisti isänmaan asiaa. Kokoelman suosikkiteemoihin kuuluvat epäon- 


\section{UUSIN LÖNNROT-MYYTTI JA KANSANRUNOUDEN EDITIOHISTORIA}

ninen teurastus sekä naapurin kotieläimen tappo seuraavaan tapaan:

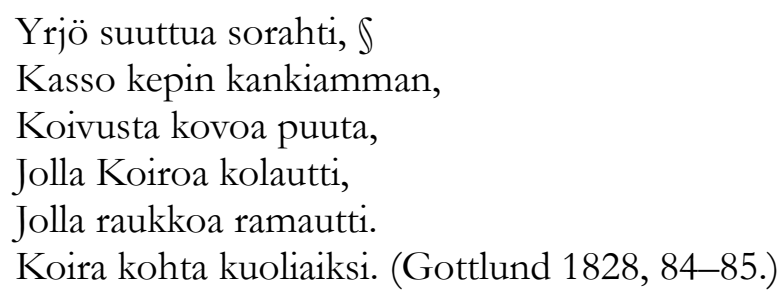

Mukana on myös kuvauksia nimettyjen aviopuolisoiden tappeluista sekä nuorten yöstelyyn liittyvistä skandaaleista ('Yötyri", "Yö-jalkalainen", "Yötymykset"). Näihin erikoistunut "tolpparin-poika" Heikki Huuhtinen hauskutti yleisöään myös runolla "Yhtymiset". Tässä nuori pari jää kiinni lehdossa rakastelemisesta. Runon loppunousu on iskevä: "Kylä kuuli - r - iänen, / Nuapurit - t - :n natinan." (Gottlund 1828, 92-103.)

Ei liene vaikea ymmärtää, että Vä̈nämöiset herätti kiukkua kansanrunouden muissa kerääjissä, julkaisijoissa ja harrastajissa. Sulkunen selviää Vä̈nämöisiin liittyvistä hankaluuksista tutulla tavallaan: hän ei anna lukijalle mitään tietoja tästä teoksesta. Näin Gottlundin marttyyrinkruunu säilyy naarmuttomana.

Gottlundin seuraava teos, Suomea ja sen kulttuuria käsittelevä tietoteos Otava (1828-1832) herätti aikalaisissa ristiriitaisia tunteita: kirjan kuvitus oli kaunis, mutta sen kieli oli omaperäistä, hankalasti avautuvaa savoa. Vämämöisistä ja Otavasta johtuen Gottlund oli ehtinyt hankkia itselleen kyseenalaisen maineen kansanrunouden julkaisijana jo 1830-luvun alussa, täysin Lönnrotista ja Kalevalasta riippumatta. (Otavan ja Väinämöisten vastaanotosta ks. Pulkkinen 2003, 116-119.)

Jo kronologisista syistä on vaikea ymmärtää, miksi Gottlundia käsittelevä jakso on Seuran historiassa niin mittava, lähes 10 sivua. (Ks. Sulkunen 2004, 63, 65-70, 72-74.) Häneen liittyviä kuviakin on kolme kappaletta, joista yksi on koko sivun laajuinen. Erikoiseksi tämän huomionosoituksen tekee se, että Gottlund ehti olla häntä käsittelevän jakson kattamana aikana, vuoteen 1841 asti, Kirjallisuuden Seuran (rivi) jäsenenä vain vajaat kolme vuotta. Lönnrot oli tuolloin Kajaanissa toimiva piirilääkäri. Voidaankin kysyä, mitä ihmettä massiivisella Gottlund-paketilla on tekemistä Kirjallisuuden Seuran historian alkujaksossa?

Yksi paketin funktioista näyttää olevan se, että se on mahdollistanut Lönnrotin esittämisen matalamielisenä ja karkeana ihmisenä. Tämä toteutuu selvimmin kohdassa, jossa Sulkunen selostaa kahdessa provinssilehdessä käytyä kiistelyä metriikasta. Vuoteen 1834 sijoittuva debatti oli saanut aiheensa Lönnrotin julkaistua uusimittaisen runon "Neijon laulu". Esitellessään tämän runomittaa Lönnrot oli viitannut moittivasti Gottlundin Otavan Homeros-käännöksiin. Gottlund vastasi haasteeseen käyttäen nimimerkkiä Pieksämäkeläinen. Hän nimitteli kriitikkoaan "äpäräksi" ja "typäräksi”. (Anttila 1985, 123.) (7)

Debatti huipentui Oulun Viikko-Sanomissa julkaistuun heksametrisäkeiden vertailuun. Osanottajia oli kolme, Gottlund, Kallio (Samuli K. Bergh) ja Lönnrot. (8) Ensimmäisenä esiteltiin Gottlundin kääntämä jakso Iliaasta: 


\section{Satu Apo}

Puhuttu: kiiruhti pois se raut'lakin-loistava Hektor ...

Kohtapa siitten hän tulikin kultaisen kotinsa luokse,

Vaan hän ej kotona löynyt Andrómache, valitun vaimon, ...

Sanoisin, että kritiikille oli jonkin verran sijaa. On syytä muistaa, että Homerosinnostus oli täydessä kukassa Suomessakin ja käännöksiä tehtiin kilpailuhengessä.

Äpäräksi ja typäräksi leimattu Lönnnrot kirjoitti vastineekseen nokkelan runon. Tämän lopun hän rakensi sananparsialluusioista, jotka sananlaskuja julkaissut ja tutkinut Gottlund tunnisti vaivatta:

Haukku ei haavoa tee, jos puulla ei lyötäne päähän.

Saavat myös vasikat hypätä ja huuhua hullut.

En kilvoittele kanssa, ja tiiät myös Sinä senki

Ett' ainet muuan paras on punnittematonna. (Anttila 1985, 125.)

Lönnrotin käyttämät sananlaskut ovat klassikkoja, jotka jo Turun akatemian opettajat olivat tallentaneet hellin käsin: "Ei haukku haavaa tee, jos ei puulla päähän lyö" (H. G. Porthan), "Hyppää vasikan kanssa, haasta kanssa hullun miehen" (R. von Becker) ja "Ei paska punniten parane" (Porthan). (Ks. Kuusi 1953, 21, 394, 6.)

Sulkusen mukaan 'Lönnrot nöyryytti 'Pieksämäkiläistä' [Gottlundia] karkeasti ja sanoutui ylimielisin sanoin julkisesti irti kiistelystä hänen kanssaan". Sulkunen paheksuu myös kiistaan liittyvää Lönnrotin yksityiskirjettä, jonka loppujaksoon sisältyy sananlasku "Ei paska punniten parane". (Lönnrot 1990a, 77). Tämänasteinen karkeus pitää toki paikkansa, mutta Lönnrotin leimaaminen jää yksipuoliseksi, kun lukijalta kätketään Gottlundin loukkaavuudet.

Outoa tai tarkoitushakuista on se, että Sulkunen pitää Lönnrotin kaikkea Gottlundiin kohdistamaa kritiikkiä osoituksena kritikoijan huonosta luonteesta. Arvostelun syyksi Sulkunen olettaa milloin kateuden, milloin loukatun kunnian, milloin oman maineen ja reviirin varjelemisen. Oudointa on se, että Lönnrotiin heittyy synkkä varjo myös silloin, kun hän ei puutu Gottlundin tekemisiin millään lailla. Tällöin hän Sulkusen mielestä syyllistyy "eristävään ja ylimieliseen vaikenemiseen". (9) Siis se, että näyttö Lönnrotin konnantöistä puuttuu, muuttuu raskauttavaksi todisteeksi.

Miltä Gottlundin tempausten arvosteleminen näyttää kirjallisuushistorian valossa? Otan esimerkiksi Sulkusen siteeraaman Lönnrotin kirjeen vuodelta 1834; tässä Lönnrot ilmaisee suuttumustaan muun muassa siksi, että Gottlund oli Otavassaan leimannut kuuluisan ruotsalaisen kansanlaulukokoelman, E. G. Geijerin ja A. A. Afzeliuksen Svenska visor frä forntiden (1814-1817) "kehnoiksi lopsutoksiksi" ja "homeiksi" verrattuna hänen omiin runoaarteisiinsa. Sulkunen ei näe Gottlundin ylilyönneissä mitään moitittavaa, päinvastoin: varjo lankeaa Lönnrotin ylle, koska hänen kirjeestään heijastuu "Gottlundiin kohdistunut ylimielinen halveksunta". (Sulkunen 2004, 70.) Tällä kohdin rohkenen kysyä, onko Sulkunen tutustunut Geijerin ja Afzeliuksen klassikkoon. Siihen sisältyy useita skandinaavisen balladirunouden helmiä, esimerkiksi Den bergtagna (Vuoren viemä) ja Bergkonungen; näiden jälkiä on nähty Aleksis Kiven Kalvean immen tarinassa. (Tarkiainen 1950, 385.) Kuuluisa runo on myös Per Tyrssons döttrar $i$ Vänge eli 
Thöres döttrar. Tarina on vaikuttanut kalevalamittaisiin kansanlauluihin (Tuurikkainen) sekä Ingmar Bergmanin Neidonlähteeseen. (Kuusi 1980, 229.) Sanoisin, että Lönnrotin suuttumus oli sekä aiheellista että pyyteetöntä.

Palaan vielä tapaan, jolla Sulkunen päättää heksametripolemiikin esittelynsä. Hän huipentaa paheksuntansa väitteeseen: "Tämän jälkeen Lönnrot ei Gottlundia töissään noteerannut." Väite on väärä. Polemiikin jälkeen Lönnrot julkaisi Kalevalansa ja potkaisi sen esipuheessa Gottlundin Otavaa. Kyse on jälleen metriikasta: "Yhtä vähä, kun mitkä 7 tähtiä olisivat Otava taivaalla, ovat mitkä 8:tavuiset sananparret hyvänsä kielessämme runoja." Tämän jälkeen seuraa kolme Gottlundilta poimittua varoittavaa esimerkkiä. (Lönnrot 1999, 14-15.) Seuraavaksi olivatkin vuorossa kohteliaisuudet. Lönnrot kirjoitti vuonna 1836 Mehiläisessä, että Gottlund on "meiltä ja muilta suomen kirjallisuuden hyväiliöiltä arvossa pidettävä oppinut”. (Majamaa 1990b, 171.) Kenties kauneimman tunnustuksen Gottlund sai Lönnrotilta vuonna 1841. Tällöin ilmestyi Kantelettaren kolmas kirja, jonka sisältönä olivat balladit ja legendat. Kirjan esipuheessa Lönnrot on omistanut helkavirsille ja Gottlundille kokonaisen kappaleen. Siteeraan siitä vain osan: "Helkavirsistä, kun myöski itsestä Helkajuhlasta, - - on Herra Akademian Lehtori C. A. Gottlundi, Otava-nimisen kirjansa 2:ssa osassa taitavasti kirjoittanut”. Tämä riittänee tavoista, joilla Elias Lönnrot teki vääryyttä C. A. Gottlundille.

\section{RUNOLAN HERKUT}

Kommentoin vielä Gottlund-draaman viimeistä näytöstä eli filosofian tohtorin ja dosentin M. A. Castrénin valitsemista Kirjallisuuden Seuran sihteeriksi vuodenvaihteessa 1840-1841. Tässä prosessissa ylioppilas Gottlundia taas "ylimielisesti nöyryytettiin". (Sulkunen 2004, 72-74.) Castréniin päätyminen merkitsi Sulkusen mukaan "lopullista kuoliniskua" Gottlundille; iskun jälkeen sen 46-vuotias uhri jaksoikin elää vain 31 vuotta. Sulkunen hahmottaa sihteerin valinnan seuraavasti: "Gottlundin kannalta olisi varmasti ollut luontevaa, että tehtävä olisi ilman muuta siirtynyt hänelle, suomen kielen lehtorin uudelle viran haltijalle." (Sulkunen 2004, 74.) Seuran kannalta Gottlundin sivuuttaminen oli enemmän kuin luontevaa, sillä hän oli ehtinyt säväyttää jälleen. Gottlund oli julkaissut keväällä 1840 yliopiston 200-vuotisjuhlan kunniaksi kalevalamittaisen eepoksen nimeltä Runola, juhlivan instituution kustantamana. Ruotsiksi kirjoittamassaan esipuheessa Gottlund väitti, ettei suomeksi ollut vielä ilmestynyt pitkää runoepiikkaa, joka olisi taiteellisesti täysipainoista. Syyksi hän esitti sen, että suomalaiset kansanrunot olivat pääosin lyyrisiä fragmentteja; näihin saattoi sisältyä myös myyttisiä ja historiallisia aihelmia. Väite oli väärä: pitkiä eeppisiä runoja, jopa laaja Lemminkäis-sikermä, oli julkaistu jo Topeliuksen kokoelmissa. Kalevalalta Gottlund kielsi taiteellisen arvon. (10)

Muissakin suhteissa Runola oli taattua Gottlundia. Kalevalaan suunnattujen potkujen lisäksi se sisältää kotikutoista fantasiaa, joka on kuorrutettu antiikkiin, pohjoismaiseen mytologiaan ja Divina Commediaan viittaavalla oppineisuudella. Sekoitus on höystetty erotiikalla ja kielipoliittisilla kannanotoilla. Eepoksen juonena on Runoilijan ja häntä opastavan Väinämöisen matkan kohti Runola-Parnassoa; määränpää muistuttaa myös 


\section{Satu Apo}

paratiisia. (11) Varmuuden vuoksi Gottlund sijoitti eepoksen tapahtumakulun unen maailmaan. Tämä vapautti kirjoittajan vastuusta - "ingen kan tadla mig för det jag drömmer" - ja turhasta arkuudesta. (Gottlund 1840, XIV-XV.)

Runolan seksiaihelmista tunnetuin on kuvaus Veden emännästä, joka kiitää matkalaisten laivan sivulla, käyttäytyen erikoisesti: "Kohtuansa koitteloopi, / Nännöjään näyskentelööpi, / Hapsiaan hajotteloopi." (Gottlund 1840, 27.) Säkeiden on arveltu viittaavan masturbaatioon. (Pulkkinen 2003, 184; Gröndahl 2002, 155-156.) Eepoksen viimeinen näytös tapahtuu Runolassa, jossa sulottaret, muusat ja muut laulun hengettäret karkeloivat Väinämöisen ja Runoilijan ympärillä. Kaunihitar eli Venus innostaa vieraitaan lemmen töihin kehumalla neitojen suloja:

Kahet kultaiset käköiset piilottaavat piika-puolet pojillehen povissansa; kahet naurihin mukurat, pari muuraman mukaiset, kahen onnelan omenat kasvaa piijan kainalossa; puhkistuvat niin kuin putket nuorten neitosten nisistä. (Gottlund 1840, 57-58.)

Kun Väinämöinen ei ikänsä vuoksi voi tarttua tarjoukseen, nuori Runoilija ryhtyy toimeen. Hän vetää syleilyynsä tenhottaren, joka oli "suloinen sukeltamoiltaan, / lihavimmiltaan ihana". Toiminta keskeytyy kuitenkin äkisti, kun sankari "menettää miehuutensa":

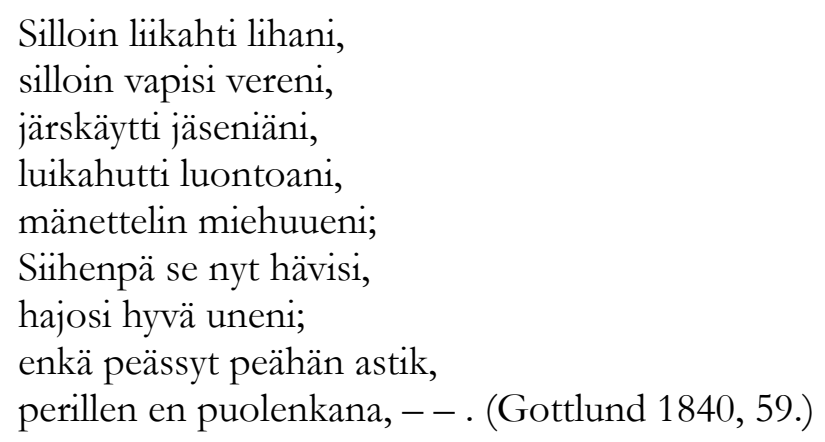

Silloin liikahti lihani, silloin vapisi vereni, järskäytti jäseniäni, luikahutti luontoani, mänettelin miehuueni; Siihenpä se nyt hävisi, hajosi hyvä uneni; enkä peässyt peähän astik, perillen en puolenkana, -- . (Gottlund 1840, 59.)

Uraauurtavien seksikuvausten lisäksi Runola on kuuluisa tyylikukkasistaan. Koska eepos on selvästi kirjoitettu myös huumorimielessä, on vaikea sanoa, mitkä niistä ovat tahallisia ja mitkä eivät. Oli niin tai näin, Heinättären hiuksissa "haisivat varpaat harakan", Väinämöinen "hosutteli housujansa" ja lauloi "lemmon laulamia, / runon hiien ruikkaamia".

Runolan esipuheen pystyivät lukemaan kaikki asiasta kiinnostuneet. Arvosteluja kirjoitettiin myös suomenkielisestä eepoksesta. Teosta puitiin lehdistössä syksyllä 1840 ja keväällä 1841. (12) Miten Sulkunen on käsitellyt Runolaa ja sen synnyttämiä 


\section{UUSIN LÖNNROT-MYYTTI JA KANSANRUNOUDEN EDITIOHISTORIA}

reaktioita? Asiahan oli hyvässä muistissa valittaessa Seuralle uutta sihteeriä. Syystä tai toisesta Sulkunen on valinnut tutun strategiansa eli vaikenemisen.

\section{EUROPAEUS - SUURI SYRJÄYTETTY?}

Myös toinen Lönnrotin väitetyistä uhreista, D. E. D. Europaeus, saa Sulkusen historiassa tilaa yli yhdeksän sivun verran. (Ks. Sulkunen 2004, 107-115, 117-118.) Europaeus oli poikkeuksellisen ansioitunut perinteenkerääjä, ja tästä häntä Lönnrot kauniisti kiittikin Uuden Kalevalan esipuheessa. Europaeusta pidetään virheellisesti Kullervo-runoston löytäjänä. Noin 18 sivun mittainen Kullervo-jakso sisältyy kuitenkin jo Vanbaan Kalevalaan. (13)

Keruukenttien ulkopuolella Europaeus oli vähemmän suvereeni. Hän oli ikuinen ylioppilas, joka mielellään ohjeisti ja välillä myös käskytti lähimmäisiään, muiden muassa Lönnrotia ja Castrénia. Edellinen sai lukea, millä tavoin hänen tulee tehdä Kalevalan uusi laitos, ja jälkimmäistä Europaeus pommitti kirjeillä, jotka sisälsivät viljalti suomalais-ugrilaisten kielten historiaa ja sukulaisuussuhteita koskevia oivalluksia. Kun Castrén hankkiutui pisimmälle Siperian matkalleen, Europaeus pyrki kiihkeästi mukaan. Häntä innoitti tieteellisten tavoitteiden ohella vieläkin jalompi päämäärä. Hän halusi jatkaa matkaansa Kiinaan, missä hänen toiveenaan oli "olla Jumalan avulla osallisena Kiinan hallitsijan ja sen jälkeen koko valtakunnan käännyttämisessä ja yrittää kaikin mahdollisin tavoin onnellistuttaa maata, ei yksinomaan Kiinaa, vaan myös muita maita ja kansanheimoja." (Timonen 1988, 207.) Syystä tai toisesta Castrén lähti tutkimusmatkalleen ilman Europaeusta.

Europaeuksen tieteellinen kiinnostus suuntautui kieli- ja muinaistutkimukseen. Monet hänen oivalluksistaan - harhaiskujen ohella - sisältyivät hänen kirjoittamiinsa kirjeisiin. Tästä syystä vasta jälkipolvet ovat päs̈sseet niitä arvioimaan. Mikään runotarten lemmikki hän ei ollut. Sanataiteilijana ja kansanrunouden kirjallistajana hän häviää sekä Lönnrotille että Gottlundille. Europaeuksen sijoittuminen kärpässarjaan näkyy niin suomenkielisen kirjallisuuden historioissa kuin lyriikan historiaa valottavissa Suomen runotar-valikoimissa. (Ks. esim. Kohtamäki 1964, 400-401.) (14) Tarkasteltavana aikana Europaeus julkaisi vain yhden runoantologian nimeltä Pieni Runon-seppä eli Kokous paraimmista Inkerinmaan puolelta kerätyistä runo-lauluista. Pieni se olikin. Teos sisälsi 28 runoa. Näistä kaunein, "Armahan kulku", on Lönnrotin tekemä. Koska useimmat runot olivat lyhyitä, teoksen runo-osio mahtuu 48 painosivuun. Runonseppä jäi Europaeuksen pääteokseksi. Parhaan vastaanoton se sai Kannaksen ja Inkerin maalaisväestön keskuudessa, missä se folkloristien harmiksi edisti suullisten lauluversioiden syrjäytymistä.

Irma Sulkunen on omistanut Runonsepälle yli sivun verran tekstiä (Sulkunen 2004, 111-112). Jälleen on outoa se, ettei hän anna lukijalle tietoja teoksen sisällöstä, eipä edes sen laajuudesta. Runonseppä oli ajan tapaan omakustanne. Europaeus otti siitä jättipainoksen (noin $4000 \mathrm{kpl}$ ). (Haltsonen 1970, 25.) Kustannustuotteena teos oli hankala siksi, että se oli kaksiosainen. Teoksen jälkimmäinen osa, jonka voi lukea myös johdantona, käsittelee kalevalamittaisen kansanrunon poetiikkaa, etenkin met- 


\section{Satu Apo}

riikkaa. Mutta Runon-sepän proosajakso sisältää paljon muutakin. Europaeus mainosti tekeillä olevaa teostaan Lönnrotille seuraavasti: 'Vieläkin ai'on panna' puhetta jatkoksi nuoihin miellyttäväisiin ja yllättäväisiin puheisiin, joita olen pannut alkuun sekä loppuun.” (Haltsonen 1970, 25.) Niin hän panikin. Alkuosa on omistettu heränneiden haukkumiselle. Nämä eivät ymmärrä Jumalasta ja hänen luomastaan kauneudesta juuri mitään. Täyden lastin saavat niskaansa myös ruotsin kieltä suosivat sivistyneet. He eivät tajua, että suomen kieli on merkittävästi parempi kuin vieraiden vaikutteiden rappeuttama ruotsi; jälkimmäinen jopa heikentää ajattelukykyä: "Mahtaa kyllä Ruotsin kielen velttosääntöinen ja vajanainen kielirakennus tehdä luonnollisen ajatuksenkin veltommaksi.” (Europaeus 1847, 58.) Sekä suomen kieli että suomalainen kansanrunous ovat Europaeuksen todistelun mukaan niin korkea-arvoisia ja kauniita, että niille tuskin löytyy ulkomailta vertaa.

Puhuessaan suomenkielisen kaunokirjallisuuden puolesta Europaeus vetosi sivistyneistöön, erityisesti nuoriin naisiin eli "neitisiin". Heidän pitäisi opetella sepittämään lyriikkaa kalevalamitalla ja säestää laulujaan kanteleella. Hän suositteli vanhan runomitan käyttämistä myös suomentamisessa, "nä’emme runolaululla olevan koko joukon ulkonaisia kauneuksia enemmin kuin kaikissa tunnetuissa ulkokielien laulutavoissa." (Europaeus 1847, 90.) Tämän vakuudeksi Europaeus esitti laatimansa käännöksen J. L. Runebergin runosta Friden (1833). Kyseessä on tiivis, yhdeksän säkeen mittainen epigrammi, jonka puhuja on nuori tyttö. (15) Kun Europaeus vapautti runon "ulkokielen laulutavasta", se paisui laajuudeltaan yli kaksinkertaiseksi. Syynä oli kalevalaisen parallelismin tunnollinen noudattaminen.

Millaisia olivat Pienen runonsepän kansanrunot? Europaeuksen laatiman alaotsikon mukaan kyseessä on "kokous paraimmista Inkerinmaan puolelta kerätyistä runo-lauluista". Suurin osa teksteistä on inkeriläisten suosimaa lyyristä epiikkaa. Tätä edustavat esimerkiksi runot "Kadonnut hanhi" ja "Kadonnut suka", "Hevosen menetys", "Kukko lensi Kuurinmaalta" ja "Tytärten hukuttaja". Kolmessa ensimmäisessä kuvataan menetyksiä: neito saa veljeltään hanhen, kadottaa sen ja löytää sen viimein kattilassa kiehumassa; neito etsii meren pohjasta pudottamaansa hiusharjaa mutta löytääkin miekan; laulaja-minä humaltuu olutta tulvivassa metsässä ja sammuu nurmelle; hänen hevosensa varastetaan, mutta kiltit vanhemmat lupaavat hankkia uuden. Kuurinmaalta lentänyt kukko laulaa ensin talon tyttären joutuvan sotaan, sitten pojan; edellisestä tiedotuksesta ilahtuu isä, jälkimmäisestä äiti. Tytärten hukuttajassa (Kelvottomassa miniässä) äiti auttaa poikaansa saamaan vaimon hukuttamalla pyykkirantaan työikäiset tyttärensä, joiden määrää miniäehdokkaat karsastavat.

Toisin kuin Irma Sulkunen väittää, Runonseppä ei ollut "läheisessä yhteydessä Kalevalaan". (Sulkunen 2004, 111.) Eepoksen teemoihin liittyviä tekstejä ovat vain "Pääskyläinen päivälintu", "Oinonsarvinen kannel" sekä "Kullervo-runo". Kahdessa edellisessä ei ollut Lönnrotin kannalta mitään uutta. Sen sijaan kolmannen alkuosa, Untamon ja Kaleva-Kalervon riita, päätyi Uuteen Kalevalaan, Lönnrotin luoman Kullervon tragedian alkukohtaukseksi. 


\section{UUSIN LÖNNROT-MYYTTI JA KANSANRUNOUDEN EDITIOHISTORIA}

\section{RUNONSEPPÄ PUNTARISSA}

Europaeuksen esittelemät inkeriläistekstit vastasivat huonosti 1840-luvun käsityksiä kauniista kansanrunoudesta. Oletan sivistyneistöön kuuluneiden lukijoiden pitäneen niitä arkisina ja epäkiinnostavina tai hankalasti avautuvina. Kun Inkeristä koottuja aineistoja alkoi saapua Seuraan, ne aiheuttivat selvän pettymyksen. Fredrik Polénin mukaan "suomalainen runotar on kadonnut Inkerinmaalla asuvaisten Suomalaisten seasta". (Sulkunen 2004, 113.) (16) Europaeuksen valikoima "paraimmista" inkeriläisrunoista ei pystynyt kilpailemaan Kalevalan ja Kantelettaren tai edes Topeliuksen Vanhojen runojen kanssa, puhumattakaan eurooppalaisista ja skandinaavisista klassikoista. Ei siis ihme, ettei Suomalaisen Kirjallisuuden Seura innostunut kirjasesta, ainakaan niin paljon, että olisi ryhtynyt sitä levittämään. Sulkunen pitää tätä "ensimmäisenä iskuna", jonka Seura kohdisti Europaeukseen. (Sulkunen 2004, 112.)

Lannistumaton Europaeus halusi teokselleen mahdollisimman paljon julkisuutta. Tässä hän myös onnistui. Johtavassa kulttuurilehdessä, J. V. Snellmanin ja Lönnrotin toimittamassa Litterturbladissa julkaistiin kaksi Runonseppää käsittelevää arvostelua. Ensimmäinen näistä ilmestyi heinäkuussa 1848. Kirjoittaja, Kuopion lukion lehtori Fabian Collan, oli lähtöisin Savosta ja osasi hyvin suomea. (Collan käytti nimimerkkiä F. K.) Collan antaa kiitosta Europaeukselle suomen kielen ja kirjallisuuden edistäjänä ja ahdasmielisten pietistien arvostelijana. Kansalle tarkoitetut huokeat runokirjaset olivat tervetulleita siksikin, että ne muodostivat vastapainon ajan massaviihteelle, arvottomina pidetyille arkkiveisuille. Collan antaa tunnustusta myös metriikkaa koskevalle osiolle. Hän kuitenkin toivoo, että vanhan runomitan lisäksi tekijä olisi esitellyt uudempia mittoja. Inkerin runoaarteet eivät innostaneet Collania. Hän olisi suonut osan näistä jääneen painamatta; tilalle olisi kannattanut ottaa uudenaikaisempia tekstejä. (Collan 1848, 205.)

Seuraavaksi kynään tarttui itse Snellman. Hänen arvostelunsa ilmestyi vuonna 1849 Litteraturbladin syyskuun numerossa, odoteltaessa Uuden Kalevalan ilmestymistä. Snellman yhtyy Collanin mielipiteisiin mutta käyttää huomattavasti ankarampia äänenpainoja. Eniten kiitosta Europaeus saa yrityksestään tuottaa huokea lukemisto rahvaan tarpeisiin. Lopputulokseen Snellman ei kuitenkaan ole tyytyväinen. Tekijä katsoo hänen mielestään taaksepäin: "Emme myöskään voi hyväksyä yhtä vähän runo-opin kuin valikoiman rajoittumista muinaisrunoihin." (Snellman 2003, $70=$ 1849, 69.) Inkerin runot eivät hurmanneet Snellmaniakaan: "Omalta osaltaan ei tämän kirjoittaja kuitenkaan pysty ymmärtämään, miksi juuri ne runot, jotka hra E. on valinnut, olisivat malleina parhaimpia." Kansanrunon aika kaunokirjallisuuden edistäjänä on jo ohi. Nyt on panostettava taiderunon kehittämiseen. Tällöin katse on suunnattava eurooppalaiseen nykyrunouteen.

Snellmanin esittämät kriittiset huomautukset vastaavat hänen kirjallisuuspoliittista linjaansa 1840-luvulla. (Ks. Karkama 1989, 11-13, 21, 75, 127-129.) Uusi laulu, myös käännöksissä, on rakennettava modernin länsieurooppalaisen runouden pohjalle, suomenkieltä taitavan sivistyneistön voimin. Näin siksikin, että "suomalaisen rahvaan suurimman osan keskuudesta on vanhojen runojen taito hävinnyt, ja niiden tilalle ovat astuneet toisenlaista runomittaa noudattavat laulut ja runot". Taidelyriikan 


\section{Satu Apo}

kehitys etenikin Snellmanin viitoittamaan suuntaan. Lönnrot ryhtyi kirjoittamaan virsiä. Hänen oppilaistaan Oksanen (August Ahlqvist) ja Suonio (Julius Krohn) loivat runonsa läntisten mallien innoittamina. Aleksis Kivi lähti puolestaan rohkeiden muotokokeilujen tielle.

Miten Irma Sulkunen on nähnyt Europaeuksen? Marttyyrina ja huippuosaajana tietenkin. Sulkusen mukaan Europaeuksesta tuli "politisoituvan fennomanian ensimmäinen suuri syrjäytetty." (Sulkunen 2004, 107.) Perussyynä Europaeuksen niin sanottuun syrjäyttämiseen eli vaikeuksiin joutumiselle vuosina 1847-1849 Sulkunen pitää Pienen runonsepän julkaisemista. Sen sijaan että etsisi syitä poliittisesti tulenarasta ajankohdasta, Europaeuksen muusta toiminnasta, hänen terveydentilastaan tai Runonsepän sisällöstä, Sulkunen esittää yllättävän väitteen. Runonseppä oli niin merkittävä julkaisu, että sen tekijä oli astumassa Lönnrotin rinnalle ja ryöstäytymässä hänen reviirilleen:

Europaeuksen teko, itsenäisesti laadittu inkeriläisrunojen kokoelma ja runousoppi, ei siis ollut loukkaus vain Lönnrotin pyhitettyä auktoriteettia kohtaan, vaan se oli myös julkea astuminen Lönnrotiin tukeutuvan ja häntä varauksetta tukevan sivistyneistön varpaille. (Sulkunen 2004, 111.)

Kirjelähteet viittaavat kuitenkin siihen, että Europaeus oli laatinut Runonseppäänsä yhteistyössä opettajansa ja suojelijansa kanssa; Lönnrot osallistui kommenteillaan ainakin runousopin tekoon. (Ks. Haltsonen 1970, 23-25.) Tämä oli luontevaa, sillä vanhan runon poetiikan ja metriikan esittely sisältyi jo Vanhan Kalevalan johdantoon.

Runonsepän ilmestyessä Lönnrot oli ehtinyt julkaista eepoksensa lisäksi Kantelettaren (1840-1841), laajan sananlaskukokoelman (1842) ja arvoituskokoelman (1844). Listaan on lisättävä vielä suuri määrä kansanrunoutta käsitteleviä kirjoituksia. Kalevala oli saanut myös kansainvälisen tiedeyhteisön siunauksen Jacob Grimmin suulla. Halusivatko Runonsepän arvostelijat kirkastaa Lönnrotin jo muutenkin suurta kunniaa vähättelemällä Europaeuksen julkaisua? Collan ja Snellman olivat Lönnrotin ystäviä. Uutta Kalevalaa laatiessaan Lönnrot neuvotteli eepokseen liittyvistä kysymyksistä heidän kanssaan. Nämä seikat eivät mielestäni vääristä heidän arvioitaan siitä, millä tavoin Pieni runonseppä saattoi edistää suomenkielisen kaunokirjallisuuden kehitystä 1850-luvun kynnyksellä. Collanin ja Snellmanin kriittiset huomiot selittyvät vahvemmin tarkastelun kohteesta kuin heidän henkilökohtaisesta suhteestaan Elias Lönnrotiin.

\section{LÖNNROT KIITTÄÄ AVUSTAJAANSA}

Europaeus oli tehnyt useiden muiden aikalaisten ohella parannusehdotuksia Uutta Kalevalaa varten. Lönnrot otti huomioon näistä käyttökelpoisimmat. Inkeristä koottua lisäaineistoa hän ei tarvinnut, Untamo ja Kalervo -runoa lukuun ottamatta. Eniten Inkerin lyyris-eeppinen runous olisi hyödyttänyt Kanteletarta, joka sisälsi lyriikkaa, häärunoja sekä balladeja ja legendoja. Kalevala oli sen sijaan eepos, ei tieteellinen aineistokokoelma, jossa eri alueiden runostot Inkeristä Vienaan olisivat olleet edustettuina. Lönnrot halusi jo työekonomian takia rakentaa Uuden Kalevalansa edellisen 


\section{UUSIN LÖNNROT-MYYTTI JA KANSANRUNOUDEN EDITIOHISTORIA}

edition pohjalle. Tämän materiaali oli peräisin pohjoisilta alueilta, Vienan Karjalasta, Pohjanmaalta, Pohjois-Karjalasta ja Savosta. (Kaukonen 1979, 58-59.) Eteläisten alueiden perinne poikkesi siinä määrin Lönnrotin jo työstämästä aineistosta, että sen käyttäminen olisi ollut hankalaa. Lisät eivät välttämättä olisi parantaneet lopputulosta. (17) Europaeus ei ymmärtänyt tätä, vaan tuputti Inkerin-löytöjään eepoksen uuden laitoksen aineksiksi.

Sulkunen yhtyy täysillä Europaeuksen käsityksiin alaluvussa "Inkeri ja Kalevala" (Sulkunen 2004, 113-114). Samalla hän yrittää määritellä Europaeuksen syrjäytymisen perimmäiseksi syyksi juuri Lönnrotin toiminnan: "Vaikuttavin taustavoima Europaeuksen kaatamisessa oli epäilemättä Lönnrot.” Tämän konnantöistä ei kuitenkaan ole esitetty selvää näyttöä. Sulkunen paikkaa aukkoa väittämällä Lönnrotin toimineen "välikäsien kautta" ja pitää raskauttavana sitä, että tietyt aikalaiset kirjoittivat hänelle Europaeuksesta "pilkallisessa ja leimaavassa hengessä, myöhemmin avoimesti mielipuoleksi nimitellen - - ". (Sulkunen 2004, 109, 113.) Entäpä jos arvostelu oli aiheellista?

Oikeudenmukainen Lönnrot katsoi, että Europaeuksen ansiot painavat enemmän kuin miehen aiheuttamat harmit. Hän kiitti suojattiaan ja yhteistyökumppaniaan kauniisti Uuden Kalevalan alkulauseessa 1849. Kiitokset hän sijoitti retorisesti vaikuttavaan kohtaan, alkulauseensa toiseksi viimeiseen pykälään. Runonkerääjiä hän luettelee kaikkiaan kahdeksan, alkaen "Akatemian oppilas" J. Fr. Cajanista ja päätyen "majisteri" H. A. Reinholmiin ja itseensä. Sitten hän jatkaa:

Erittäinkin onnistui Europaeukselle paljo sekä uusia runoja että toisintoja entisiin, vuosina 1845, 1846 ja 1848, kerätyksi saada. Näistä hänen ja muiden ilmi saattamista suurista runokokouksista, jotka ynnä entisten kokousten kanssa tulevat Helsingissä olevalta Suomalaisen Kirjallisuuden Seuralta säilytettäväksi, on nykyinen Kalevalan laitos kasvanut pian toistansa isommaksi ja laajemmaksi, kuin minkä entinen oli. Minkä ilmanki, runojen järestyksessä ja muussa sisällisessä kohdassa, lienee entistä laitosta parempi, se asia jääköön itsekunki lukian arvata.

Lönnrot liitti kiitoksiinsa vielä Europaeuksen teosta mainostavan alaviitteen: "Hän on myös kirjaansa: Pieni Runon-seppä, Hels. 1847 liitetyssä johdatuksessa runon tekoon laatinut osaavasti runojen mitteellisestä rakennuksesta ja antanut hyviä neuvoja siitä asiasta tarkempaa tietoa haluaville."

Vaikka Kalevalaa kirjoittava Lönnrot ei innostunut Europaeuksen inkeriläisistä löydöistä, hän ei hyljeksinyt Inkeriä kuten ei Seurakaan. H. A. Reinholm sai keruumatkalleen rahoituksen vuosina 1847-1848, August Ahlqvist ja K. A. Slöör 1855, Ahlqvist uudestaan 1856, A. B. Stråhlman 1857, J. Länkelä 1859, J. S. Tallqvist, O. F. Saxbäck ja A. Törneroos vuonna 1860. Kahdeksan viimeistä rahoitusmyöntöä ajoittuu kauteen, jolloin Seuran esimiehenä oli Elias Lönnrot (1854-1863) ja sihteerinä Sven Gabriel Elmgren (1846-1861). (18) 


\section{Satu Apo}

\section{Gottlund, Europaeus ja Sulkunen arvioivat Kalevalaa}

Kalevalan reseptiota käsiteltäessä on syytä muistaa, ettei 1830-1840-luvulla ollut olemassa selkeitä normeja, joiden avulla olisi voitu arvioida Lönnrotin onnistumista tehtävässään. Suomalais-karjalaisen kansanrunouden systemaattinen tutkimus odotti vielä syntyään. Lönnrotin aikana kansanrunous oli materiaalia, jota muokattiin julkaisutarkoituksiin monin tavoin, niin Suomessa kuin Euroopassakin. Suurelle yleisölle tarkoitetut, kansanrunouteen pohjaavat julkaisut miellettiin kaunokirjallisuudeksi, ei tarkoiksi näytteiksi suullisesta laulukulttuurista. Kansanrunouden muokkaajan tuli kuitenkin varoa kahta asiaa: omaa sepittämistä sekä lähteiden hävittämistä. Tämä oli opittu Ossiania koskevasta pitkästä kiistasta. (19) Lönnrot katsoi selviävänsä autenttisuusongelmista siten, että hän sepitti uusia säkeitä mahdollisimman vähän. Hän myös pysytteli kansanrunojen tapahtumakulkujen ja henkilöasetelmien puitteissa poikkeamatta näistä ainakaan jyrkästi. Viime kädessä hän vetosi laulavaan kansaan. Kuka tahansa, joka lähtisi kiertelemään Karjalan kyliin, voisi omin korvin kuulla Kalevalasta tuttujen runojen kaikuvan rahvaan keskuudessa. Eepoksensa lähteet Lönnrot lupasi toimittaa Suomalaisen Kirjallisuuden Seuran kirjastoon. Lupaus on kirjattu Kalevalan kummankin laitoksen esipuheeseen.

Lönnrot kuitenkin piti omat ja muiden kerääjien käsikirjoitukset hallussaan kiusallisen pitkään, vuoteen 1874 asti. (Apo 2008, 372.) Niinpä runotallenteiden ja Kalevalan väliset suhteet jäivät aikalaisille hämäriksi. Vain ne, jotka olivat itse keränneet vanhamittaista kansanrunoutta, pystyivät mittailemaan eepoksen etäisyyttä lähteistään. Muutamat kerääjät (A. I. Arwidsson, Gottlund, Europaeus) "paljastivat" saman asian kuin Lönnrot itse Kalevalansa esipuheissa: Suomen kansan keskuudesta ei voida löytää eeposta. Toisenkin paljastuksen Lönnrot oli tehnyt oma-aloitteisesti: kirjoituksessaan Anmärkningar till den nya Kalevala upplagan (1849) hän rinnasti eepoksensa ja sen laatimistavan Homerokseen. (Ks. esimerkiksi Lönnrot 1993, 408.)

Gottlund ja Europaeus kyseenalaistivat arvioissaan sekä Kalevalan juonirakenteen että Lönnrotin lavean kerrontatavan, jossa oli hyödynnetty loitsujen, häärunojen ja lyyristen laulujen säkeitä. Gottlund ilmaisi kantansa 1840-luvun lopulla seuraavasti:

Täksi tarpeiksi [saadakseen aikaan jotakin Iliaan veroista] hään milloin taitavasti, milloin taitamattomasti siihen mätti ja sevotti varsin eriluontoisia ja eriaikuisia aineita, ja sotki tähän kaikellaisia loihteita ja salvurinsanoja, pitkiä rauvan-, maon- ja muihen jälkiä, naimavirsiä ja muita niitä näitä joutavia lauseheita, sillä että aina jollon kullon siihenki oli pistetty Väinämöisen, Ilmarisen tahi jonkun toisenki nimen;-- . (Heikinheimo 1960, 13.)

Europaeus ei elinaikanaan julkaissut Kalevalaan kohdistuvaa kritiikkiä. Uuden Kalevalan ilmestyttyä hän tyytyi Suomettaressa (1849) paheksumaan eepoksessa käytettyä kirjasintyyppiä: tämä ei enää ollut koristeellinen fraktuura vaan arkinen antiikva, "latinan puustavi”. Europaeuksen jäämistöstä löytyi 1850-luvulla laadittu käsikirjoitus, jossa hän asetti vastatusten luonnonrunouden, "parhaiden laulajien suusta pulpunneet runot", ja Lönnrotin säekompilaatiot: 


\section{UUSIN LÖNNROT-MYYTTI JA KANSANRUNOUDEN EDITIOHISTORIA}

Aidossa muodossaan runot ovat yhtenäisiä, ripeästi eteneviä, niissä on luovan mielikuvituksen ehjää täyteläisyyttä, kun taas jo Kalevalan ensimmäisessä painoksessa lukija kohtaa selvän muokkaustyön, tiivistämisen, venyttämisen ja selittämisen jälkiä, - - . (Europaeus 1988, 189.)

Europaeus uskoi virheellisesti, että Kalevalassa käytetyillä "aidoilla lauluilla" - joita on runsaasti - on keskinäinen yhteys, jonka "aina täytyy tulla näkyviin". Keskushenkilöt olivat Väinämöinen ja Pohjan neito. Lönnrotin "teennäinen yhdistely" oli sotkenut luonnolliset liittymät. Vuonna 1853 Europaeus haaveili luomu-Kalevalasta, joka olisi puhdistettu "ukko E. L.:n" muokkaustyöstä:

Todellisiin lauluihin pohjautuva uusi laitos on sen vuoksi suorastaan välttämätön, enkä minä haluaisi itseäni ikuisesti pidettävän miehenä, joka on kokoelmillaan saattanut Kalevalan nykyiseen asuunsa. (Kaukonen 1988, 78.)

Europaeus ei ehkä tullut ajatelleeksi, että "todellisiin lauluihin pohjautuva" kansanrunoeepos olisi jo oppineen tekijän tuottamaa kirjallisuutta, samaan tapaan kuin ukko E. L:n luomus. (Kaukonen 1988, 77-78.) Kansanrunoja idealisoiva Europaeus ei myöskään ottanut huomioon, että suulliset runot ovat parhaimmillaan laulettuina, ihmisääneen, melodiaan ja esitystilanteeseen yhdistettyinä. Kun runotallenteet toimittajan paranteleminakin - luetaan pelkkinä paperille painettuina teksteinä, ne rinnastuvat kaunokirjallisuuteen, eivätkä aina edukseen. Matti Kuusi muotoili tämän ongelman vuonna 1980 seuraavasti:

Tosiasia on, ettei audiovisuaalisista puitteistaan riisuttu, savupirttiympäristöstään painokoneeseen siirretty aito kansanrunoteksti hevin sytytä nykysuomalaista. - - Jotakin on siis tehtävä tekstille, tai nykysuomalaiselle. (Kuusi 1980, 9.) (20)

Lönnrot ratkaisi ongelman tekemällä laulutallenteista kirjallisen eepoksen ja veti Gottlundiin ja Europaeukseen verrattuna pisimmän korren.

Irma Sulkunen yhtyy täysin rinnoin Gottlundin ja Europaeuksen Kalevala-kritiikkiin. Gottlundin onnistui paljastaa Lönnrot Kalevalan tekijäksi; hän kertoi lisäksi tämän käyttäneen eepostekstin rakentamisessa monenkirjavia aineksia. (Sulkunen 2004, 63.) Näin ei ilmeisesti olisi saanut tehdä. Europaeuksen Kalevala-kritiikkiä Sulkunen pitää "terävästi argumentoituna". (Sulkunen 2004, 115.) Runonsepän tekijän kyvyt ovat tehneet häneen niin suuren vaikutuksen, että hän arvioi Europaeuksen vähintään yhtä päteväksi Kalevalan laatijaksi kuin sen luojan: 'Epäilemättä Europaeus omasta mielestään ja ehkä objektiivisestikin ottaen myös tiesi Lönnrotia paremmin, millainen Uudesta Kalevalasta piti tehdä.” (Sulkunen 2004, 110.)

Sulkusen muista oivalluksista mainittakoon syytös Vanhan Kalevalan karjalaistamisesta savolaisuuden kustannuksella. Sulkusen mukaan Lönnrot otti käyttöön "savolaisuutta kansanperinteestä häivyttävän luokittelutavan", kun hän "nimesi Kalevalankin 


\section{Satu Apo}

'vanhoiksi karjalaisiksi runoiksi', vaikka suuri osa niistä oli koottu nimenomaan savolaiselta murrealueelta”. (Sulkunen 2004, 68.) Sulkuselta on jäänyt huomaamatta eepoksen alaotsikon loppuosa: Kalevalan runot kertoivat Suomen kansan muinosista ajoista eli pakanuuden ajasta. Tuolloin Savon heimoa ei ollut olemassa, eipä ajan historiankäsityksen mukaan vielä "paavin aikanakaan". Savolaiset irtautuivat itäisestä pääheimosta eli karjalaisista vasta myöhemmin. Romantiikan aikana kansanrunous miellettiin kautta Euroopan viestiksi hyvin etäisestä muinaisuudesta, joko keskiajalta tai esikristilliseltä kaudelta. Tämä käy ilmi myös 1830-1840-luvulla ilmestyneistä Suomen historian oppikirjoista. (21)

\section{VALO, VARJO JA VAKUUTTAVUUS}

Miksi Irma Sulkunen on epäonnistunut käsitellessään Lönnrotin, Gottlundin ja Europaeuksen muodostamaa triangelia? Syitä voidaan etsiä hänen tietopohjastaan ja metodologiastaan. Sulkuselta puuttuvista teoreettisista työvälineistä ehkä tärkein on kirjallisuustieteen genreteoria ja siihen liittyen tiedot lajien historiasta 1700-1800-luvulla. Tämän seurauksena hänellä on vaikeuksia erottaa eepos runokokoelmasta. Kun Sulkunen kirjoittaa Kalevalasta, lukijalle ei aina selviä, onko kyseessä kokoelma, kooste, sarja sikermiä vai kokonaisjuonen yhdistämä pitkä kertomus eli eepos. Lönnrotin monipolvisen ja luovaa panosta vaatineen työprosessin Sulkunen kaventaa useimmiten koostamiseksi tai kokoamiseksi. Hänellä ei myöskään näytä olevan kuvaa siitä, mikä oli muinaisaikaa käsittelevän eepoksen kulttuurinen merkitys Euroopassa ja Suomessa 1800-luvun alkupuoliskolla. Tämä on mahdollistanut pikkukokoelmia julkaisseiden Gottlundin ja Europaeuksen nostamisen arvoon arvaamattomaan.

Kysymyksiä herättää myös Sulkusen metodologia. Tätä hän kuvaa seuraavasti: "Toiminnan sisäistä dynamiikkaa - - jäljitän vaihtamalla tarkastelukulmia, laskeutumalla henkilökohtaisen vaikuttamisen tasolle ja nostamalla analyysin keskiöön vuoroin voittajat, vuoroin häviäjät." (Sulkunen 2004, 12.) Dynamiikkaan toki saadaan lisää kierroksia, jos Seuran piirissä tai liepeillä tapahtunut toiminta hahmotetaan Hollywood-konseptin mukaisesti, valtakamppailuna, jossa voidaan selkeästi erotella toisistaan voittajat ja häviäjät. Tieteelliseen ja taiteelliseen toimintaan liittyviä "voittoja" ja "häviöitä" ei kuitenkaan kannata selittää viihteen mallein, tulkitsemalla ne kierojen pelien tuloksiksi, ellei tulkintaa pystytä perustelemaan myös pelaajien suoritusten asiantuntevalla ja kattavalla analyysilla.

Sulkusen konfliktihakuinen lähestymistapa suuntaakin huomion pois Seuran ja sen yksittäisten jäsenten toiminnan tärkeimmistä tuloksista, julkaistuista teoksista. Näihin kyllä vedotaan, mutta lukija saa aivan liian vähän tietoa teosten sisällöistä ja näihin liittyneistä ideologisista ja tieteellisistä keskusteluista. Kun sisällöt sivuutetaan, Pieni runonseppä ja Kalevala alkavat näyttää yhteismitallisilta saavutuksilta.

Lisää metodisia ongelmia kertyy, kun Seuran piirissä käytyihin kamppailuihin kohdistetaan vaihtelevia valaistusjärjestelyjä: 


\section{UUSIN LÖNNROT-MYYTTI JA KANSANRUNOUDEN EDITIOHISTORIA}

Lähestymistapoja yhteen sitovaa käsitettä nimitän "varjoksi". Monitulkintaisena käsite ilmentää hyvin ensiksikin pyrkimystäni nostaa Kirjallisuuden Seuran historiakuvaan myös aiemmin piiloon jääneitä toimijoita ja heidän edustamiaan sisällöllisiä aineksia. Toiseksi käsite muistuttaa siitä, että jokaisella kanonisoituneellakin vaikuttajalla oli omat varjonsa: yhtäältä oman persoonallisuuden piilotetut puolet ja toisaalta ne toimijat, jotka jäivät suurmiehiksi korotettujen varjoon joko heidän tukijoinaan tai syrjäytettyinä vastapooleinaan. Kolmanneksi varjo-käsite havainnollistaa tutkimuksellisen asemoinnin vaikutusta tulkintaan. Valotusta vaihtamalla myös varjot lankeavat toisin, jolloin kokonaiskuvakin piirtyy uudenlaisena. Monoliittisuuden sijaan se alkaa elää dynaamisesti liikkuvina valta- ja toimintakeskuksina. (Sulkunen 2004, 12.)

Ajatus on kiehtova, mutta kysymys intersubjektiivisuudesta painaa päälle jo raskaasti. Onko valotusta säätävä tutkija itsevaltias, jonka ei tarvitse ottaa huomioon aiempien tutkijoiden analyyseja ja tulkintoja? Onko uudenlaisen kokonaiskuvan rakentaminen itsetarkoitus? Entäpä jos tällä menetelmällä on saatu aikaan vain uusi, sensaatiomainen myytti toimijoista ja prosesseista, joiden lähdeaineistoihin vain harvat tutkijat jaksavat kaivautua?

Sulkusen ymmärtämisen ja selittämisen tavoissa näyttävät yhdistyvän psykohistoria ja manikealaisuus. Yhdistelmä on tuottanut vetäviä tarinoita, historiallisia melodraamoja, jotka "hävinneiden" osalta on kerrottu kyyneleitä hersyttävällä tyylillä. Ongelmaksi nousee kuitenkin tietokirjaksi, ehkä tutkimukseksikin tarkoitetun teoksen laadunvarmistus. Subjektiivisuuden ja argumentoinnin vakuuttavuuden välinen jaakobinpaini on päättynyt Lönnrotia, Gottlundia ja Europaeusta käsittelevissä jaksoissa subjektiivisuuden kirkkaaseen voittoon.

\section{VIITTEET}

1. Risto Pulkkinen on väitöskirjassaan (2003) tarkastellut Gottlundin persoonallisuutta ja sen mahdollisia psykopatologisia piirteitä. Kalle Achté laati vastaavan arvion Europaeuksesta vuonna 1988.

2. Gunnar Castrénin $(1945,412)$ mukaan kyseessä on A. J. Sjögrenille osoitettu kirje. (Vrt. Timonen 1988, 209-210.) Aikalaisten arvioita Gottlundin henkilöstä näkyy Pulkkisen tutkimuksessa runsaasti (ks. esimerkiksi Pulkkinen 2003, 116-117).

3. Runoja Europaeuksen kokoelmassa on 48 sivun verran. Teoksen toinen osa, 1848 ilmestynyt Johdatus runon tekoon, on yhtä laaja.

4. Topelius julkaisi vanhamittaista kansanrunoutta yli 170 painosivun verran. Suuri osa teksteistä edusti kaikkein arvokkaimpana pidettyä aineistoa, myytti-, sankari- ja loitsurunoutta. Vrt. Apo 2004, 277-279.

5. Kansanperinteeseen viitataan Seuran säännöissä monin ilmaisuin. Seuran tarkoituksena oli koota Suomen "entisaikoihin, runokeinoon, muinaisuskoon - - " liittyviä tietoja painatteista ja käsikirjoituksista. Tarkoitus oli kokoilla myös "suomalaisia 


\section{Satu Apo}

lauluja" ja "vanhoja tarinoita". Ks. Sulkunen 2004, 64.

6. Esitellessään Kultalaa Sulkunen ei kerro mitään Lönnrotiin liittyneistä julkaisuhankkeista (Sulkunen 2004, 43). Zschokkesta ja hänen teoksestaan ks. Karkama 2007.

7. Yksityiskirjeissään Gottlund saattoi käyttää vieläkin railakkaampaa kieltä, niinpä Vïpurin Sanomien toimittajat saivat osakseen luonnehdinnan "nuokin sian v-tut". (Pulkkinen 2003, 167-168.)

8. Näytteistä onnistunein oli sitaatti Kallion kuuluisasta elegiasta "Oma maa" (1832). Sulkusen $(2004,79)$ mukaan kyseessä oli "Bergh-Kallion Homeros-käännöksen katkelma". Ks. Anttila 1985, 122-126.

9. "Ehkä loukkaavampaa kuin avoin taistelu, johon Gottlund oli aina valmis, oli se eristävä ja ylimielinen vaikeneminen, johon ainakin Lönnrot syyllistyi." (Sulkunen 2004, 69.)

10. "Ej blott all vår gamla folkpoesi, utan äfven allt hvad den Finska Sångens fatebur sedermera producerat, består blott i smärre lyriska stycken, äfven om ock dessa någongång skulle behandla ett mytiskt eller historiskt ämne. Någon originel större komposition af vidsträktare omfång har hos oss ännu icke sett dagen, hvilken man skulle kunna tillerkänna namnet af ett fulländadt konststycke.” (Gottlund 1840, II.)

11. Nousu Parnassolle on viittaus promootioon, joka huipensi yliopiston 200-vuotisjuhlan.

12. Runolaa esiteltiin suhteellisen neutraalisti Borgå Tidning'issä (No. 85, lokakuun 31. päivä 1840). Sopimattomana pidettiin väitettä, ettei suomeksi ole vielä julkaistu mitään laajaa runoteosta, jota voitaisiin pitää sanataiteena. Helsingfors Morgonblad'issa julkaistiin kaksiosainen arvio (Nro:t 28-29, huhtikuun 15 ja 19 päivä 1841). Se on tyyliltään kohtelias mutta sisällöltään viiltävän ivallinen. Runolan synnyttämä paheksuminen näkyy myös M. A. Castrénin vuonna 1841 ilmestyneessä Kalevalan ruotsinnoksessa. Castrén (1841, IV) viittaa Runolan esipuheeseen, jonka mukaan Kalevala voisi sisältää vain kansanrunojen fragmentteja.

13. Vanhan Kalevalan Kullervo on taitamaton orja, jonka leipään emäntä kätkee kiven, kohtalokkain seurauksin (19. runo).

14. Gottlund ja Lönnrot ovat saaneet sijansa vuosien 1965 ja 1990 Suomen Runottaressa sekä Veikko Polameren Runojen kirjassa (1977).

15. Runo ilmestyi 1833. Se sisältyy Runebergin kokoelmaan Dikter II, osastoon "Idyll och epigram”. Ks. Runeberg 1899, 284.

16. Sulkunen tulkitsee Inkerin runojen arvostelemisen Lönnrotin myötäilyksi, viittaamatta näiden runojen ominaisuuksiin.

17. Julius Krohn liitti kokeilumielessä Unden Kalevalan Kullervo-jaksoon Inkeristä saatuja säkeitä. Hän totesi, etteivät lisäykset parantaneet eivätkä pahentaneet Lönnrotin tekstiä. Kalevala oli paras pitää sellaisena kuin se oli tekijänsä kynästä lähtenyt. Ks. Krohn 1882, III-IV.

18. Inkerin keruita koskevat rahoitustiedot eivät tue Matti Kuusen $(1988,26)$ esittämää arvelua: "Ilmeisesti juuri Lönnrot seuran esimiehenä piti yllä käsitystä Inkerin runojen arvottomuudesta." Vuosien 1849-1854 tauko ylioppilaiden lähettämisessä Inkeriin, Pietaria ympäröivälle maaseudulle, selittynee epävakaista poliittisista oloista eli vallankumousvuoden 1848 jälkivaikutuksista ja Krimin sodasta (1853-1855). 
19. James Macpherson väitti eepoksensa (1760-1763) perustuvan 200-luvulla tehtyyn gaelinkieliseen käsikirjoitukseen, joka sisälsi mestaribardi Ossianin laulamia runoja. Kun Ossianin lähteitä eli vanhoja käsikirjoituksia vaadittiin esiin, Macpherson ei niitä näyttänyt. (Apo 2006, 224, 233-236.)

20. Matti Kuusi suhtautui Kalevalaan jyrkän kielteisesti. Hän julkaisi 1976 KansanrunoKalevalan, temaattisesti ryhmitellyn kokoelman kertovia kansanrunoja. Tekstit ovat toimittajan muokkaamia. Kansanruno-Kalevalan oli tarkoitus syrjäyttää Kalevala kouluopetuksessa.

21. Ks. esimerkiksi Arwidsson 1832. Lönnrotin ajan historiankirjoitusta on esitellyt kansanrunouden kannalta Karkama (2002, 245-258).

\section{LÄHTEET}

\section{Tutkimusaineistot}

BORGÅ TIDNING 1840: Literatur. [Arvostelu C. A. Gottlundin Runolasta.] Nro 85, 31.10.1840.

CASTRÉN, M. A. 1841: Kalevala. Öfversatt av M. A. Castrén. Helsingfors.

COLLAN, FABIAN 1848: Inhemsk Litteratur. (Arvostelu D. E. D. Europaeuksen Pienestä runonsepästä). - Litteraturblad Nro 8 (heinäkuu 1848).

EUROPAEUS, D. E. D. 1847: Pieni Runon-seppä eli Kokous paraimmista Inkerinmaan puolelta kerätyistä runo-lauluista ynnä Johdatuksia Runon tekoon. Helsinki.

— 1849: Mistäs syystä latinan puustavit kauniimpia olisivat kuin tavalliset Suomen puustavit? - Suometar 42.

- 1988: Julkaisemattomia artikkeleita: Suomen sisäisistä kansallisista oloista sekä suomalaisen kansallishengen heräämisestä, kehityksestä ja pyrkimyksistä. - Kuusi, Matti \& Laaksonen, Pekka \& Timonen, Senni (toim.), D. E. D. Europaeus. Suurmies vai kummajainen. Helsinki: SKS.

GEIJER, E. G. \& AFZELIUS, A. A. 1880: Svenska visor frän forntiden (1814-17). Stockholm: Z. Haeggströms förlagsexpedition.

GOTTLUND, C. A. 1985: Pieniä Runoja Suomen poijille Ratoxi I (1819-21). Helsinki \& Tukholma: Suomalais-ruotsalainen Kulttuurirahasto.

- 1828: Vä̈nämö̈set, ykesi kokous meïän nykyisten runojoin virren-teoista. Tukhulmi.

- 1828-1832: Otava I-II. Tukhulmi.

- 1840: Runola. Till lugnets hem och fridens hvar går diktens skepp frän Vandas strand. Bland ljusa moln och mörka skyar syns saingens Ö och sagans land. Helsingfors: Kejserliga Alexanders-Universitetet i Helsingfors.

HELSINGFORS' MORGONBLAD 1841: Inhemsk litteratur. [Nimimerkki -i-. Arvostelu C.A.Gottlundin Runolasta.] Numerot 28 ja 29, 15.4.1841 ja 19.4.1841.

KROHN, JULIUS 1882: Kullervon runot. Inkerin toisinnoista lisätty uusi painos. Helsinki: SKS.

LÖNNROT, ELIAS 1985: Väinämö̈nen, muinaissuomalaisten jumala. (Dissertatio de Väinä- 
möine, priscorum Fennorum numine. I, 1827). Suomentanut Iiro Kajanto. Helsinki: SKS. - 1829-1831: Kantele taikka Suomen Kansan sekä Vanhoja että Nykysempiä Runoja ja Lauluja. Helsinki.

- 1999: Kalevala taikka vanhoja Karjalan runoja Suomen kansan muinosista ajoista. Helsinki: SKS. [1835]

— 1966: Kanteletar elikkä Suomen kansan vanhoja lauluja ja virsiä. Helsinki: SKS. [1840]

- 1964: Kalevala. Helsinki: SKS. [1849]

- 1990a: Valitut teokset 1. Kirjeet. Toim. Raija Majamaa. Helsinki: SKS.

- 1990b: Valitut teokset 2. Mebilä̈nen. Toim. Raija Majamaa. Helsinki: SKS.

- 1993: Valitut teokset 5. Muinaisrunoutta. Toim. Raija Majamaa. Helsinki: SKS.

PIKKANEN, ILONA 2004: Ensimmäiset kaksitoista. - Sulkunen, Irma, Suomalaisen Kirjallisuuden Seura 1831-1892. Helsinki: SKS.

RUNEBERG, J. L. 1899: Samlade arbeten. II. Helsingfors: G. W. Edlunds förlag.

SNELLMAN, J. V. 1849: Inhemsk Litteratur. [Arvostelu D. E. D. Europaeuksen Pienestä runonsepästä]. Nro 9 (syyskuu 1849).

- 2003: Kootut teokset 12. Heinäkuи 1849-elokun 1855. Toim. Raimo Savolainen et alii. Helsinki: Opetusministeriö.

SULKUNEN, IRMA 2004: Suomalaisen Kirjallisunden Seura 1831-1892. Helsinki: SKS.

TIMONEN, SENNI 1988: D. E. D. Europaeuksen kirjeitä vuosilta 1846-1882. Kuusi, Matti \& Laaksonen, Pekka \& Timonen, Senni (toim.), D. E. D. Europaeus. Suurmies vai kummajainen. Helsinki: SKS.

TOPELIUS, ZACHARIAS 1822-1831: Suomen Kansan Vanboja Runoja ynnä myös nykyisempiä lauluja. I- $V$. Turku ja Helsinki.

Kirjallisuus

ACHTÉ, KALLE 1988: Europaeuksen persoonallisuudesta. - Kuusi, Matti \& Laaksonen, Pekka \& Timonen, Senni (toim.), Suurmies vai kummajainen. Helsinki: SKS.

ANTTILA, AARNE 1985: Elias Lönnrot. Elämäja toiminta. Helsinki: SKS. [1931/1935]

APO, SATU 2004: Laulaen vai kirjallisesti luoden? Uuden Kalevalan valmistusprosessi Elias Lönnrotin kuvaamana. - Siikala, Anna-Leena \& Harvilahti, Lauri \& Timonen, Senni (toim.), Kalevala ja laulettu runo. Helsinki: SKS.

- 2006: Kansanlaulujen ääni 1700-luvun kirjallisuudessa. - Ollitervo, Sakari \& Immonen, Kari (toim.), Herder, Suomi, Eurooppa. Helsinki: SKS.

- 2008: Kansanrunouden tutkijat Kalevalan kriitikkoina. - Piela, Ulla \& Knuuttila, Seppo \& Laaksonen, Pekka (toim.), Kalevalan kulttuuribistoria. Helsinki: SKS.

ARWIDSSON, A. I. 1832: Lärobok i Finlands historia och geografi. Åbo.

CASTRÉN, GUNNAR 1945: Herman Kellgren. Ett bidrag till 1840- och 1850-talens kulturbistoria. Helsingfors: Svenska Litteratursällskapet i Finland.

GROOM, NICK 1999: The Making of Percy's Reliques. Oxford: Clarendon Press.

GRÖNDAHL, SATU 2002: Kaarle Aksel Gottlundin Runola - torso vai edelläkävijä? - Hahnsson, Heidi \& Kangassalo, Raija \& Lindmark, Daniel (toim.), När språk och kulturer möts. Festskrift till Tuuli Forsgren 2 november 2002. Umeå: Skrifter utgivna av Johann Nordlander-sällskapet 24. 
HALTSONEN, SUlO 1970: Pieni Runon-seppä. Tilkkeitä D. E. D. Europaenksen kirjailijakuvaan. - Jublakirja Eino Kauppisen täyttäessä 60 vnotta 26.2.1970. Tampere: Tampereen yliopisto.

HEIKINHEIMO, ILMARI 1960: Gottlund ja Lönnrot. Porvoo: WSOY.

KARKAMA, PERTTI 1989: J. V. Snellmanin kirjallisunspolitiikeka. Helsinki: SKS.

— 2002: Kansakunnan asialla. Elias Lönnrot ja ajan aatteet. Helsinki: SKS.

— 2007: Kullan tekemisen aakkoset. Heinrich Zschokken Goldmacherdorf ja sen suomennos. - Stark, Eija \& Stark, Laura (toim.), Kansanomainen ajattelu. Helsinki: SKS.

KAUKONEN, VÄINÖ 1979: Lönnrot ja Kalevala. Helsinki: SKS.

- 1988: Europaeuksen osa Kalevalan laadinnassa. - Kuusi, Matti \& Laaksonen, Pekka \& Timonen, Senni (toim.), D. E. D. Europaeus. Suurmies vai kummajainen? Helsinki: SKS.

KOHTAMÄKI, ILMARI 1964: Suomenkielisen kirjallisuuden elpyminen. - Viljanen, Lauri (toim.), Suomen kirjallisuus III. Turun romantikoista Aleksis Kiveen. Helsinki: SKS ja Otava.

KUUSI, MATTI (toim.) 1953: Vanhan kansan sananlaskuviisaus. Suomalaisia elämänohjeita, kansanaforismeja, lentäviä lauseita ja kokekapubeita vuosilta 1544-1826. Porvoo: WSOY.

- (toim.) 1976: Kansanruno-Kalevala. Helsinki: Otava.

— (toim.) 1980: Kalevalaista kertomarunoutta. Helsinki: SKS.

KUUSI, MATTI \& TIMONEN, SENNI 1988: Suurmies? Kummajainen? Uhrilammas? Keskustelua Europaeuksen elämästä ja työstä. - Kuusi, Matti \& Laaksonen, Pekka \& Timonen, Senni (toim.), D. E. D. Europaeus. Suurmies vai kummajainen. Helsinki: SKS.

POLAMERI, VEIKKO (toim.) 1977: Runojen kirja. Neljä vuosisataa suomalaista runoutta. Helsinki: Otava.

PULKKINEN, RISTO 2003: Vastavirtaan. C. A. Gottlund 1800-luvun suomalaisena toisinajattelijana: psykobiografinen tutkimus. Helsinki: Yliopistopaino.

PÄÄKKÖNEN, IRMELI 1994: Suomalainen sydämestä. Carl Niclas Keckmanin toiminta suomen kielen kehittäjänä. Helsinki: SKS.

STAFFORD, FIONA 1988: The Sublime Savage. James Macpherson and the Poems of Ossian. Edinburgh: Edinburgh University Press.

Suomen runotar 1965: Toim. Suomen Kirjailijaliiton asettama toimituskunta. Helsinki: Weilin \& Göös.

Suomen runotar 1 1990: Toimittaneet Kankaanpää, Hannu \& Marttila, Satu \& Polkunen, Mirjam. Helsinki: Kirjayhtymä.

TARKIAINEN, VILJO 1950: Aleksis Kivi. Elämä ja teokset. Porvoo: WSOY.

\section{Satu Apo on folkloristiikan professori Helsingin yliopistossa.}

